\title{
Validation and Psychometric Properties of the Brazilian Version of the Subjective Happiness Scale*
}

\section{Validación y propiedades psicométricas de la versión brasileña de la Escala de Felicidad Subjetiva}

Recibido: octubre 12 de 2012 | Revisado: agosto 12 de 2013 | Aceptado: octubre 1 de 2013

\author{
Bruno Figueiredo DAMÁSIO ** \\ CRISTIAN ZANON *** \\ Sílvia Helena KOLLER ${ }^{* * * *}$ \\ Federal University of Rio Grande do Sul, Brazil
}

doi:10.11144/Javeriana.UPSY13-1.vppb

Para citar este artículo: Damásio, B. F., Zanon, C., $\&$ Koller, S. H. (2014). Validation and psychometric properties of the Brazilian version of the Subjective Happiness Scale. Universitas Psychologica, 13(1), 17 24. doi:10.11144/Javeriana.UPSY13-1.vppb

The present research was approved by the Federal University of Rio Grande do Sul Research Ethics Committee (Institutional Review Board). As authors, we certify our participation in the development of the present paper, making public the responsibility of its content. All the authors have agreed to authorship in the following order: 1- Bruno Figueiredo Damásio; 2- Cristian Zanon; 3- Sílvia Helena Koller.

** Assistant Professor of the Federal University of Rio de Janeiro (Department of Psychometrics/Institute of Psychology) - UFRJ. Corresponding author: Pasteur Avenue, 150, Postal code: 22290-902.

*** Assistant Professor of the São Francisco University, Itatiba, São Paulo, Brazil.

**** Titular professor of the Federal University of Rio Grande do Sul - UFRGS.

\section{A B S T R A C T}

This paper aimed to adapt the Subjective Happiness Scale to Brazil and gather evidences of construct validity to the scale. Participants were 600 subjects ( $50 \%$ men), aged from 18 to 70 years old $(M=30.1 ; S D=10.6)$. Sample was split to cross-validate the results. Exploratory factor analysis $\left(N_{1}=300\right)$ achieved a reliable single-factor solution, with all items loading satisfactorily on the factor. Confirmatory factor analysis $\left(N_{2}=300\right)$ corroborated the singlefactor solution with excellent goodness-of-fit indexes. Evidences of convergent validity are also provided with three related constructs: self-esteem, life satisfaction and hope. The adapted scale showed strong evidences of validity and seems appropriate to evaluate subjective happiness on Brazilian adults. Keywords authors

Subjective Happiness Scale, test adaptation, positive psychology, psychometrics.

Keywords plus

Brazil, factor analysis, happiness, scale, subjective.

\section{RESUMEN}

El objetivo de este artículo fue adaptar la Escala de Felicidad Subjetiva para el Brasil y recolectar evidencias de validez de constructo para la escala. Los participantes fueron 600 sujetos (50\% hombres), con edades entre 18 y 70 años $(M=30.1 ; D E=10.6)$. La muestra fue dividida para realizar la validación cruzada de los resultados. En el análisis factorial exploratorio $\left(N_{1}=300\right)$ se encontró una solución unifactorial fiable, con todos los ítems presentando carga factorial satisfactoria en el factor. El análisis factorial confirmatorio $\left(\mathrm{N}_{2}\right.$ $=300$ ) corroboró la solución unifactorial con adecuados índices de ajuste. Se presentan evidencias de validez convergente con tres constructos similares: autoestima, satisfacción con la vida y esperanza. La versión adaptada presentó fuertes evidencias de validez, siendo considerada apropiada para evaluar la felicidad subjetiva en adultos brasileños.

Palabras clave autores

Escala de Felicidad Subjetiva, adaptación de instrumento, psicología positiva, psicometría.

Palabras clave descriptores

Brasil, análisis factorial, felicidad, escala, subjetivo. 
The scientific study of happiness is one of the most challenging issues in psychological research. The construct has been investigated for at least 5 decades (Bradburn \& Caplovitz, 1965; Diener, 1984; Kammann, Christie, Irwin, \& Dixon, 1979), and has been influenced by other areas, such as Philosophy (Aristotle), Economics (Caporale, Georgellis, Tsitsianis, \& Yin, 2009; Easterlin, McVey, Switek, Sawangfa, \& Zweig, 2010; Graham, 2009), Psychiatry and Neurosciences, in general (Kringelbach \& Berridge, 2010; O'Connor, Dinan, \& Cryan, 2011), in order to understand which are the constituents of happiness and how people can act towards its development.

During this period, several instruments were developed to evaluate this construct, such as: Affect Balance Scale (Bradburn, 1969), Affectometer (Kammann \& Flett, 1983), Affective Intensity Measure (Larsen, 1984), Global Happiness Scale (Fordyce, 1977), Positive and Negative Affect Schedule ([PANAS]; Watson, Clark, \& Tellegen, 1988). The main foundation of these questionnaires was the idea that happiness is the high frequency of positive affect $(\mathrm{PA})$ and low frequency of negative affect ([NA]; Diener, 1984; Diener, Sandvik, \& Pavot, 1991). Thus, many researchers used the index PA minus NA as a procedure to quantify happiness.

This idea, however, is not totally accepted (Kashdan, Biswas-Diener, \& King, 2008; Ryan \& Deci, 2001), once these authors have argued and provided empirical evidences that: 1 ) people who face negative events (and consequently negative affects) can present high levels of happiness depending on the meaning and adaptation process attributed to the situation or affect experienced (e.g., Larsen \& Prizmic, 2008), and 2) not all positive affect leads directly to happiness increase, because of the phenomenon of hedonic adaptation (Lyubomirsky, 2010).

Nowadays, it is well known that happy individuals are more successful across multiple life domains than the unhappy ones (Liubomirsky, King, \& Diener, 2005). In general, people tend to perceive themselves in positive affect states when important areas of their lives are going well. On this perspective, positive affect is a reflex of the positive evaluation of many different areas. These areas and their re- spective importance (such as marriage, friendship, income, work performance, health, etc) are, however, different across cultures, so it is quite difficult to cross-culturally compare the levels of happiness within a specific-domain approach (Diener, 2000). Thus, two main problems emerged in the definition and measurement of happiness: it could not be anymore defined as the single predominance of PA over NA, and the measurement of specific domains could hamper and limit a global comprehension of happiness across different cultures.

The first approach to evaluate happiness in a non-theoretical perspective was proposed by Lyubomirsky and Lepper (1999). These authors presented a "subjective" measure of happiness, entitled Subjective Happiness Scale (SHS, Lyubomirsky \& Lepper, 1999). This instrument was the first attempt to evaluate happiness without including any a priori definition of the construct. In other words, the SHS evaluates happiness without considering what happiness is (Lyubomirsky, Sheldon, \& Schkade, 2005). Once happiness might present different conceptions and causes across people, the advantage of this approach is to allow respondents to define their own levels of happiness, and the only relevant aspect to report is the one related to how happy respondents think they are.

Since its publication, the SHS has been widely accepted, because of its adequate psychometric properties, factorial stability and briefness. The SHS has been translated into several languages, such as Arabic (Moghnie \& Kazarian, 2011), European Portuguese (Spagnoli, Caetano, \& Silva, 2010), German and Tagalog (Swami et al., 2009), Japanese (Shimai, Otake, Utsuki, Ikemi, \& Lyubomirsky, 2004), Malay (Swami, 2008), etc. The adapted version of the scale to Brazil might allow local clinicians, social psychologists and lawmakers to assess happiness in a very straightforward way. In addition, once happiness is considered one of the most important things in life, researchers might benefit from the scale because they will be able to study the construct more in depth, as well as to find out possible differences of happiness across the country. The objective of this study is to present the 
adaptation process and the psychometric properties of a Brazilian-Portuguese version of the Subjective Happiness Scale.

\section{Method}

\section{Participants}

Participants were 600 subjects ( $50 \%$ men), aged from 18 to 70 years old $(M=30.1 ; S D=10.6)$, from 22 Brazilian states. A total of $63.7 \%$ was single, 25.5\% married, $5.3 \%$ divorced, $5.1 \%$ in cohabitation and $0.4 \%$ widow. This sample is composed by participants who took part of a larger study entitled "Meaning in life and subjective well being: Relations with optimism, hope, self-efficacy and self-esteem in different stages of the life spam", which aims to evaluate personal and contextual factors related to the positive psychological functioning.

\section{Instruments}

Subjective Happiness Scale (SHS): The SHS is a 4-item test that evaluates happiness from the respondent's own perspective. The instrument has presented excellent psychometric properties in several countries (Moghnie \& Kazarian, 2011; Spagnoli et al., 2010; Shimai et al., 2004; Swami et al., 2009; Swami, 2008). In the validation study (Lyubomirsky \& Lepper, 1999), the authors found adequate reliability index, with alpha coefficients varying from 0.80 to 0.94 in 14 different samples $(N=2.732)$

The adaptation process of the original SHS to the Brazilian-Portuguese included several steps, based on the International Test Commission guidelines (ITC, 2010) and on Borsa, Damásio and Bandeira (in press). Initially, the questionnaire was translated from English to Portuguese by two independent groups of translators who were instructed to emphasize the meaning and not the literal expressions on the translations. With these two versions, the authors conducted a synthesis of the instrument.

This synthesis was evaluated by a target-group $(N=4)$ and by a group of three researchers, psychol- ogists and experts in psychometric evaluation. In this process, some difficulties emerged and were reviewed. For example, the original SHS presents anchors only to the first and the last points of the rating scale and they are not the same to the four items. Because this kind of rating-scale is not common in most Brazilian psychological questionnaires, and the target-group found it difficult to comprehend, a third anchor was added in the mid-point for each of the four items (see Annex). Furthermore, it was added a sentence explaining that the respondents can select any number between 1 and 7. This adapted version was back-translated from Portuguese to English by a third independent translator, and this version was evaluated by one American researcher, expert on the topic of subjective happiness and specifically, on the SHS. After the approval, the instrument was considered ready to use.

Rosenberg Self-Esteem Scale (RSS): The Brazilian version of the RSS was adapted and validated by Hutz and Zanon (2011). It is a one-dimensional measure, composed by ten items, which evaluate general self-esteem (e.g., "I feel that I have a number of good qualities). In the validation study, the scale presented adequate psychometric properties, with reliability index $(\alpha)$ of 0.9 .

Satisfaction with Life Scale (SWLS): The Brazilian version of the SWLS was adapted and validated by Gouveia, Milfont, da Fonseca, and Coelho (2009). The instrument is composed by five items, which evaluate life-satisfaction from a subjective perspective (e.g., "In general, I am satisfied with my life). In the validation study, the scale presented adequate psychometric properties (Reliability index, $\alpha=0.8$; goodness-of-fit indexes (GFI $=0.99$; NNFI $=0.98$; $\mathrm{CFI}=0.99 ; \mathrm{RMSEA}=0.06$; $\mathrm{SRMR}=0.021$ ).

Dispositional Hope Scale (DHS): The Brazilian version of the dispositional hope scale was adapted and validated by Pacico (2011). It is composed by 12 items (4 are distractors, and are not considered in the analysis), which evaluate hope in a single-factor structure. Four items are related to the sense of determination through personal objectives (e.g., "I energetically pursue my goals") and four items are related to cognitive evaluation, people do about the way they will achieve their objectives (e.g., "I can 
think of many ways to get the things in life that are most important to me"). In the Brazilian validation study a single-factor solution was achieved with adequate reliability index $(\alpha=0.82)$.

\section{Data Collection}

Participants were assessed through different sources: Personal and media invitations, and snowball technique (Patton, 1990). Those who decided to participate answered a web-based survey. A free-consent term was added in the first page of the survey, so that participants could only advance in the questionnaire by accepting the terms of it, and giving their consent in participating in the study.

\section{Data Analysis}

The total sample was randomly split to evaluate the factor structure of the Brazilian version of the SHS. An exploratory factor analysis (EFA) was conducted with the first half $\left(N_{1}=300\right)$, using Principal Axis Factoring extraction method. The sample adequacy was assessed by the Kaiser-Meyer-Olkin (KMO) and Bartlett's sphericity test measures. Reliability was assessed using the Alpha coefficient.

A confirmatory factor analysis (CFA) was then performed with the second group $\left(\mathrm{N}_{2}=300\right)$ to cross-validate the obtained exploratory factor structure. The robust maximum likelihood extraction method (i.e., with corrections to data non-normality (Satorra \& Bentler, 2001) was used in the CFA (this analysis was conducted using EQS 6.1). The fit indices used were: the chi-square to degrees-of-freedom ratio $\left(s-b \chi^{2} / d f\right)$, the root mean square error of approximation (RMSEA), the standardized root mean square residual (SRMR), the comparative fit index (CFI), and the Tucker-Lewis index (TLI).

According to guidelines, a model fit presents acceptable amount of errors if the following values are achieved: s-b $\chi^{2} / d f$ ratio less than 3 , SRMR less than 0.08, RMSEA less than 0.08 (considering the $90 \%$ confidence interval), and CFI and TLI values greater than 0.9 (preferably greater than 0.95 (Brown, 2006; Schreiber, Stage, Nora, \& Barlow, 2006).
Evidences of convergent validity were assessed through correlations of the subjective happiness (SHS) with life satisfaction (SWLS), general self-esteem (GSE) and dispositional hope (DHS) in the total sample $(N=600)$. Positive and moderate correlations among these variables were expected.

\section{Results}

\section{Exploratory Factor Analysis}

EFA $\left(\mathrm{KMO}=0.79\right.$; Bartlett's test of sphericity $\chi^{2}[6]$ $381.427, p<0.001)$ presented a single-factor solution, which accounted for $64.21 \%$ of the explained variance of the construct. All items loaded in the factor, with adequate factor loadings (i.e., $>0.3$, see Table I). The Alpha coefficient was 0.84.

\section{Confirmatory Factor Analysis}

CFA was conducted with the second half of the sample using absolute, parsimony, and comparative fit indexes, as recommended by Brown (2006). Excellent fit indexes were achieved: $s-b \chi^{2}=0.329$, $d f=2, p=0.84 ; \mathrm{CFI}=1.0 ; \mathrm{TLI}=1.02 ; \mathrm{SRMR}=$ 0.006; RMSEA $(90 \% \mathrm{CI})=0(0$ - 0.006).

\section{Convergent Validity}

Pearson's correlations among subjective happiness, satisfaction with life, self-esteem and hope were per-

\section{TABLE 1}

Exploratory Factor Analysis of the Brazilian Version of the Subjective Happiness Scale

\begin{tabular}{cc}
\hline & Factor \\
\hline & Subjective Happiness \\
\hline Item 1 & 0.82 \\
Item 2 & 0.74 \\
Item 3 & 0.65 \\
Item 4 & -0.69 \\
\hline Eigenvalue & 2.56 \\
Explained Variance & $64.21 \%$ \\
Alpha Coefficient & 0.84 \\
Mean (SD) & $20.04(5.13)$ \\
\hline
\end{tabular}

Source: Own Work. 
formed in the total sample $(N=600)$ (see Table 2). As expected, subjective happiness correlated significantly with life satisfaction, hope and self-esteem. The magnitudes of the correlations were all positive and moderate (ranging from 0.48 to 0.66 ), as previously reported (Lyubomirsky \& Lepper, 1999).

\section{Discussion and Final Considerations}

The Brazilian version of the SHS presented excellent psychometric properties. All items loaded in the expected factor, and CFA results provided excellent fit. Convergent validity also presented results in the expected directions and offered support to the external validity of the measure. Positive correlations of subjective happiness with self-esteem and hope suggest that happier people also tend to present higher levels of self-esteem and are more hopeful. From the correlation between subjective happiness and satisfaction with life $(r=0.66)$, it is possible to see that both variables evaluate similar but different constructs. Both are related to a positive self-perception, however, while the first assesses the level of global happiness, the second measures the level of global life contentment.

These results are in coherence with the original and all other adapted versions of the SHS (Moghnie \& Kazarian, 2011; Shimai et al., 2004; Spagnoli et al., 2010; Swami, 2008; Swami et al., 2009), and suggest that the SHS is a valid and reliable measure to evaluate subjective happiness in Brazil. Future researches are suggested in order to test the validity of the SHS in different Brazilian samples, such as with clinic patients and across cultures. The main limitation of this study is to not be based on a representative Brazilian sample.

\section{References}

Borsa, J. C., Damásio, B. F., \& Bandeira, D. R. (in press). Adaptação e validação de instrumentos psicológicos entre culturas: Algumas considerações [Adaptation and validation process of psychological measures among cultures: Some considerations]. Paidéia.

Bradburn, N. M. (1969). The structure of psychological wellbeing. Chicago: Aldine Publishing.

Bradburn, N. M., \& Caplovitz, D. (1965). Reports on happiness. Chicago: Aldine.

Brown, T. A. (2006). Confirmatory factor analysis for applied research. New York: The Guilford Press.

Caporale, G. M., Georgellis, Y., Tsitsianis, N., \& Yin, Y. P. (2009). Income and happiness across Europe: Do reference values matter? Journal of Economic Psychology, 30(1), 42-51. doi:10.1016/j.joep.2008.06.004

Diener, E. (1984). Subjective well-being. Psychological Bulletin, 95(3), 542-575.

Diener, E. (2000). Subjective well-being: The science of happiness and a proposal for a national index. American Psychologist, 55(1), 34-43. doi:10.1037/0003066X.55.1.34

TABLE 2

Means, Medians, Standard Deviations, Reliabilities and Correlation Matrix of Measured Variables

\begin{tabular}{lcccc}
\hline & 1 & 2 & 3 & 4 \\
\hline 1. Subjective happiness & $(0.81)$ & & & \\
2. Life satisfaction & 0.66 & $(0.85)$ & $(0.87)$ & $(0.81)$ \\
3. Self-esteem & 0.57 & 0.61 & 0.62 & $31.37(8-40)$ \\
4. Hope & 0.48 & 0.54 & $32.5(10-50)$ & 31 \\
\hline M (possible range) & $20.1(4-28)$ & $24.9(5-35)$ & 33 & 3.93 \\
Mdn & 21 & 26 & 4.87 & \\
SD & 5.07 & 5.82 & & \\
\hline
\end{tabular}

Note. 1 - Subjective happiness (SHS); 2 - Life satisfaction (SWLS); 3 - Self-esteem (RSS); 4 - Hope (DHS). Values in parenthesis along the main diagonal represent internal consistency estimates (Alpha coefficient). M - Mean; Mdn - Median; SD - Standard deviation. All correlations were significant at $p<0.001$

Source: Own Work. 
Diener, E., Sandvik, E., \& Pavot, W. (1991). Happiness is the frequency, not the intensity, of positive versus negative affect. In F. Strack, M. Argyle \& N. Schwarz (Eds.), Subjective well-being (pp. 119-139). Oxford: Pergamon.

Easterlin, R. A., McVey, L. A., Switek, M., Sawangfa, O., \& Zweig, J. S. (2010). The happiness-income paradox revisited. Proceedings of the National Academy of Sciences, 107(52), 22463-22468. doi:10.1073/ pnas. 1015962107

Fordyce, M. W. (1977). Development of a program to increase personal happiness. Journal of Counseling Psychology, 24, 511-520.

Graham, C. (2009). Happiness around the world: The paradox of happy peasants and miserable millionaires. New York: Oxford University Press.

Gouveia, V. V., Milfont, T. L., da Fonseca, P. N., \& Coelho, J. A. P. de M. (2009). Life satisfaction in Brazil: Testing the psychometric properties of the Satisfaction with Life Scale (SWLS) in five Brazilian samples. Social Indicators Research, 90(2), $267-$ 277. doi: $10.1007 / \mathrm{s} 11205-008-9257-0$

Hutz, C. S., \& Zanon, C. (2011). Revisão da adaptação, validação e normatização da Escala de Autoestima de Rosenberg [Revision of the adaptation, validation, and normatization of the Roserberg SelfEsteem Scale]. Avaliação Psicológica, 10(1), 41-49.

International Test Commission. (2011). ITC Guidelines of Adapting Tests. Retrieved from http://www. intestcom.org

Kammann, R., Christie, D., Irwin, R., \& Dixon, G. (1979). Properties of an inventory to measure happiness (and psychological health). New Zealand Psychologist, 8, 1-9.

Kammann, R., \& Flett, R. (1983). A scale to measure current level of general happiness. Australian Psychologist, 35(1), 259-265.

Kashdan, T. B., Biswas-Diener, R., \& King, L. A. (2008). Reconsidering happiness: The costs of distinguishing between hedonics and eudaimonia. The Journal of Positive Psychology, 3(4), 219-233. doi:10.1080/17439760802303044

Kringelbach, M. L., \& Berridge, K. C. (2010). The neuroscience of happiness and pleasure. Social Research: An International Quarterly, 77(2), 659-678. doi:10.1016/j.tics.2009.08.006
Larsen, R. J. (1984). Theory and measurement of affect intensity as an individual difference characteristic. Dissertation Abstracts International, 85, 2297B (University Microfilms No. 84-22112)

Larsen, R. J., \& Prizmic, Z. (2008). Regulation of emotional well-being: Overcoming the hedonic treadmill. In M. Eid \& R. J. Larsen (Eds.), The science of subjective well-being (pp. 258-289). New York: Guilford Press.

Lyubomirsky, S. (2010). Hedonic adaptation to positive and negative experiences. In S. Folkman (Ed.), Oxford handbook of stress, health, and coping (pp. 200225). New York: Oxford University Press.

Lyubomirsky, S., King, L., \& Diener, E. (2005). The benefits of frequent positive affect: Does happiness lead to success? Psychological Bulletin, 131(6), 803855. doi:10.1037/0033-2909.131.6.803

Lyubomirsky, S., \& Lepper, H. S. (1999). A measure of subjective happiness: Preliminary reliability and construct validation. Social Indicators Research, 46(1), 137-155. doi:10.1023/A:1006824100041

Lyubomirsky, S., Sheldon, K. M., \& Schkade, D. (2005). Pursuing happiness: The architecture of sustainable change. Review of General Psychology, 9(2), 111131. doi:10.1037/1089-2680.9.2.111

Moghnie, L., \& Kazarian, S. S. (2011). Subjective happiness of Lebanese college youth in Lebanon: Factorial structure and invariance of the Arabic Subjective Happiness Scale. Social Indicators Research, 109(2), 203-210. doi:10.1007/s11205-011-9895-5

O'Connor, R. M., Dinan, T. G., \& Cryan, J. F. (2011). Little things on which happiness depends: MicroRNAs as novel therapeutic targets for the treatment of anxiety and depression. Molecular Psychiatry, 17(4), 359-376. doi:10.1038/mp.2011.162

Pacico, J. C. (2011). Adaptação e validação de instrumentos de avaliação de esperança [Adaptation and validation of assessment instruments of hope]. Unpublished master thesis, Post-Graduation Program of Psychology, Federal University of Rio Grande do Sul, Porto Alegre, Brazil.

Patton, M. Q. (1990). Qualitative evaluation and research methods (2nd. ed.). Newbury Park: Sage.

Ryan, R. M., \& Deci, E. L. (2001). On happiness and human potentials: A review of research on hedonic and eudaimonic well being. Annual Review 
of Psychology, 52(1), 141-166. doi:10.1146/annurev. psych.52.1.141

Satorra, A., \& Bentler, P. M. (2001). A scaled difference chi-square test statistic for moment structure analysis. Psychometrika, 66(4), 507-514. doi:10.1007/ BF02296192

Schreiber, J. B., Stage, F. K., King, J., Nora, A., \& Barlow, E. A. (2006). Reporting structural equation modeling and confirmatory factor analysis results: A review. The Journal of Educational Research, 99(6), 324-337. doi:10.3200/JOER.99.6.323-338

Shimai, S., Otake, K., Utsuki, N., Ikemi, A., \& Lyubomirsky, S. (2004). Development of a Japanese version of the Subjective Happiness Scale (SHS), and examination of its validity and reliability. Nihon Koshu Eisei Zasshi, 51(10), 845-853.

Spagnoli, P., Caetano, A., \& Silva, A. (2010). Psychometric properties of a Portuguese version of the Sub- jective Happiness Scale. Social Indicators Research, 105(1), 137-143. doi:10.1007/s11205-010-9769-2

Swami, V. (2008). Translation and validation of the Malay Subjective Happiness Scale. Social Indicators Research, 88(2), 347-353. doi:10.1007/s11205007-9195-2

Swami, V., Stieger, S., Voracek, M., Dressler, S. G., Eisma, L., \& Furnham, A. (2009). Psychometric evaluation of the Tagalog and German Subjective Happiness Scales and a cross-cultural comparison. Social Indicators Research, 93(2), 393-406. doi:10.1007/s11205-008-9331-7

Watson, D., Clark, L. A., \& Tellegen, A. (1988). Development and validation of brief measures of Positive and Negative Affect: The PANAS Scales. Journal of Personality and Social Psychology, 54(1), 1063-1070. doi:10.1037/0022-3514.54.6.1063 


\section{APPENDIX}

Instruções: Para cada uma das seguintes afirmações ou perguntas faça, por favor, um círculo em torno do número da escala que você pensa ser o mais apropriado para descrevê-lo. Você pode escolher qualquer número de 1 a 7.

Em geral, eu me considero:

\begin{tabular}{llllll}
\hline \multicolumn{1}{c}{1} & 2 & 4 & 5 & 6 & 7 \\
\hline $\begin{array}{l}\text { Uma pessoa } \\
\text { não muito feliz }\end{array}$ & & $\begin{array}{l}\text { Nem infeliz, } \\
\text { nem feliz }\end{array}$ & & $\begin{array}{l}\text { Uma pessoa } \\
\text { muito feliz }\end{array}$ \\
\hline
\end{tabular}

Comparado à maioria dos meus colegas/amigos, eu me considero:

\begin{tabular}{cccccc}
\hline 1 & 2 & 3 & 5 & 6 & 7 \\
\hline Menos feliz & \multicolumn{5}{c}{$\begin{array}{c}\text { Nem menos feliz, } \\
\text { nem mais feliz }\end{array}$} \\
\hline
\end{tabular}

Algumas pessoas, de maneira geral, são muito felizes. Elas aproveitam a vida independentemente do que esteja acontecendo, conseguindo o máximo de cada situação. Em que medida essa caracterização descreve você?

\begin{tabular}{cccccc}
\hline 1 & 2 & 4 & 5 & 6 & 7 \\
\hline Nem um pouco & & $\begin{array}{c}\text { Nem pouco, } \\
\text { nem muito }\end{array}$ & Muito \\
\hline
\end{tabular}

Algumas pessoas, de maneira geral, não são muito felizes. Embora não estejam deprimidas, elas nunca parecem tão felizes quanto poderiam ser. Em que medida essa caracterização descreve você?

\begin{tabular}{cccccc}
\hline 1 & 2 & 4 & 5 & 6 & 7 \\
\hline Nem um pouco & \multicolumn{3}{c}{$\begin{array}{c}\text { Nem pouco, } \\
\text { nem muito }\end{array}$} & Muito \\
\hline
\end{tabular}

